\title{
Microbiome analyses and presence of cable bacteria in the burrow sediment of Upogebia pugettensis
}

\author{
Cheng Li ${ }^{1, *}$, Clare E. Reimers ${ }^{1}$, John W. Chapman ${ }^{2}$ \\ ${ }^{1}$ College of Earth, Ocean, and Atmospheric Sciences, Oregon State University, Corvallis, Oregon 97331, USA \\ ${ }^{2}$ Department of Fisheries and Wildlife, Oregon State University, Hatfield Marine Science Center, \\ 2030 SE Marine Science Dr. Newport, Oregon 97365, USA
}

\begin{abstract}
We utilized methods of sediment cultivation, catalyzed reporter deposition-fluorescence in situ hybridization, scanning electron microscopy, and 16s rRNA gene sequencing to investigate the presence of novel filamentous cable bacteria $(\mathrm{CB})$ in estuarine sediments bioturbated by the mud shrimp Upogebia pugettensis Dana and also to test for trophic connections between the shrimp, its commensal bivalve (Neaeromya rugifera), and the sediment. Agglutinated sediments from the linings of shrimp burrows exhibited higher abundances of CB compared to surrounding suboxic and anoxic sediments. Furthermore, CB abundance and activity increased in these sediments when they were incubated under oxygenated seawater. Through core microbiome analysis, we found that the microbiomes of the shrimp and bivalve shared 181 taxa with the sediment bacterial community, and that these shared taxa represented $17.9 \%$ of all reads. Therefore, bacterial biomass in the burrow sediment lining is likely a major food source for both the shrimp and the bivalve. The biogeochemical conditions created by shrimp burrows and other irrigators may help promote the growth of $\mathrm{CB}$ and select for other dominant members of the bacterial community, particularly a variety of members of the Proteobacteria. These associations give new understanding to the ecology of a burrowing crustacean that is common, but in decline, throughout intertidal mudflats of Northeastern Pacific estuaries.
\end{abstract}

KEY WORDS: Upogebia pugettensis - Sediment bioturbation - Electrogenic sulfur oxidation · Cable bacteria $\cdot$ Neaeromya rugifera

\section{INTRODUCTION}

North American thalassinid mud shrimp Upogebia pugettensis Dana populate and form dense beds of burrows in estuarine mudflat sediments from Prince William Sound, Alaska, to Morro Bay, California (USA) (Williams 1986, Chapman et al. 2012). The burrows of Upogebia exert significant biogeochemical influences on their wider benthic environments (Aller et al. 1983, D'Andrea \& DeWitt 2009). All species of Upogebia excavate permanent Y-shaped burrows with stable linings and 2 surface openings (Thompson \& Pritchard 1969, Kinoshita 2002, Kinoshita \& Itani 2005). Their

\footnotetext{
*Corresponding author: cheng.li@oregonstate.edu
}

burrows can penetrate deep into anoxic sediment zones. The approximately $3 \mathrm{~mm}$ thick sediment linings of Upogebia burrows are meticulously maintained, coated with a mucopolysaccharide mixture produced in the hindgut gland of the shrimp, and subjected to other shrimp activities including bioirrigation (Thompson 1972). Irrigation by Upogebia maintains oxygen saturation in the burrow at about $30-40 \%$ at high tide (Koike \& Mukai 1983) and at $~ 10 \%$ during tidal lows when the mudflats are exposed (Thompson \& Pritchard 1969). Detrital organic matter may also accumulate in and around shrimp burrows and mounds (Kinoshita et al. 2003, D'Andrea \& DeWitt 2009).

(C) The authors 2020. Open Access under Creative Commons by Attribution Licence. Use, distribution and reproduction are unrestricted. Authors and original publication must be credited. 
Below the mudflat surface and centimeters away from the burrow linings, the sediments that Upogebia occupy are mainly suboxic and can be anoxic during ebbtide when physical irrigation is reduced (Johns et al. 1997). Sulfate reduction is a major pathway of mineralization in anoxic organic-rich sediment (Jørgensen 1982). Consequently, hydrogen sulfide is produced and then precipitated in the form of metal sulfides. Thus, the environment surrounding Upogebia burrows is dynamic in space and time, with the burrows serving as conduits that introduce oxygen and organic matter to radiating suboxic and sulfidic sediment zones. Diverse communities of microorganisms benefit from such biogeochemical zonation. Observations suggest that densities of bacterial microflora in Upogebia burrow linings can be approximately 3 times greater than in the adjacent non-burrow sediment (Kinoshita et. al 2003). However, the importance of these burrow-associated bacterial communities to the shrimp has remained uninvestigated.

Among the microbes that are capable of taking advantage of the burrow lining environment are novel, filamentous, cable bacteria (CB) within the family Desulfobulbaceae (Trojan et al. 2016), which have recently gained considerable attention. CB employ electron transfer along extracellular ridges connecting 100 s to 1000 s of cells in filaments to perform electrogenic sulfur oxidation, which couples 2 separated half-cell redox reactions of sulfide oxidation and oxygen reduction (Pfeffer et al. 2012). The spatial separation of redox half-reactions and the associated transfer of electrical current by CB can extend over centimeters and creates localized porewater $\mathrm{pH}$ extremes in near-surface sediments. These conditions will often induce a series of secondary geochemical reactions that include the dissolution of iron sulfide $(\mathrm{FeS})$, calcium carbonate $\left(\mathrm{CaCO}_{3}\right)$, and manganese carbonate $\left(\mathrm{MnCO}_{3}\right)$ (Risgaard-Petersen et al. 2015, Seitaj et al. 2015, Sulu-Gambari et al. $2016 a, b)$. These secondary reactions significantly change the availability of $\mathrm{Fe}, \mathrm{Ca}, \mathrm{Mn}$, and $\mathrm{P}$ at depth, and thereby exert substantial geochemical influence on the benthic environment (Rao et al. 2016, SuluGambari et al. 2016a,b).

CB with differing cell morphologies have been documented as occurring in surficial sediments from diverse habitats, including intertidal mudflats, mangroves, rivers, salt marshes, bivalve reefs, and groundwater aquifers (Pfeffer et al. 2012, Larsen et al. 2015, Malkin \& Meysman 2015, Risgaard-Petersen et al. 2015, Müller et al. 2016, Malkin et al. 2017). The sediments from these locations are reported generally to be without extreme levels of bioturbation or resuspension. Recently, Aller et al. (2019) found CB in a sediment zone that is heavily bioturbated by the parchment worm Chaetopterus variopedatus, suggesting that certain types of bioturbation do not limit the activity of $\mathrm{CB}$. To date, no study has reported the presence of $\mathrm{CB}$ in sediment bioturbated by Upogebia. More importantly, how the activities of Upogebia may affect the growth of $\mathrm{CB}$, or whether the microbiota of burrow linings may be critical for mud shrimp, has not been resolved.

In the present study, we utilized methods of sediment cultivation, catalyzed reporter depositionfluorescence in situ hybridization (CARD-FISH), scanning electron microscopy (SEM), and high-throughput 16s rRNA gene sequencing, to investigate the microbiology of the sediments associated with $U$. pugettensis burrows and to verify the presence of CB. Additionally, we examined trophic relationships by analyzing the bacterial communities in pooled tissue samples from the gut system of $U$. pugettensis and from the digestive organs of an obligate commensal bivalve, Neaeromya rugifera (Carpenter). The overarching goal was to reveal the connection between the sediment bacterial community and the ecology and gut microbiome of the shrimp.

\section{MATERIALS AND METHODS}

\subsection{Sampling site and collections}

The principal samples for this study were collected at low tide from Idaho Flat in Yaquina Bay, Oregon (USA) $\left(44.618344^{\circ} \mathrm{N}, 124.041247^{\circ} \mathrm{W}\right)$. Sediment cores that intersected Upogebia pugettensis burrows were collected using a $15 \mathrm{~cm}$ inner diameter by $1.5 \mathrm{~m}$ length, pneumatically operated deep corer. We confined our sampling to burrows of reproductive-size shrimp by sampling only burrows greater than $22 \mathrm{~mm}$ in diameter. As the deep core does not capture entire burrows, we inferred the ' $U$ ' and ' $I$ ' sections of the Y-shaped burrows from their sediment depths. Previous resin casts of $U$. pugettensis burrows have revealed that the 'I' part of adult shrimp burrows usually begins at greater than $20 \mathrm{~cm}$ depth from the sediment surface (Thompson 1972, J. W. Chapman pers. obs.).

Sediment samples were collected during 2 sampling trips (Table 1). On the first (8 June 2018), distinctly visible sections of burrows were exposed after whole-core extrusion and then sampled (both above and below $20 \mathrm{~cm}$ depths). Plugs ( $\mathrm{n}=3$ ) of burrow-lining sediment (designated UB-S), approximately $0.5 \mathrm{~cm}$ 
Table 1. Details of sample collections and experiments performed. See Fig. 1 for an illustration of the sampling scheme in relationship to burrow structures. CARD-FISH: catalyzed reporter deposition-fluorescence in situ hybridization

\begin{tabular}{|c|c|c|c|c|}
\hline $\begin{array}{l}\text { Sample/ } \\
\text { expt }\end{array}$ & Details & Collection date & Treatment & Treatment date \\
\hline \multicolumn{5}{|c|}{ Prescreen of cable bacteria prior to sediment cultivation } \\
\hline UB-S & Sediment lining of Upogebia burrow & 8 June 2018 & CARD-FISH & 8 June 2018 \\
\hline \multicolumn{5}{|c|}{ Sediment cultivation experiment } \\
\hline UB-U & Burrow-lining sediment harvested $<20 \mathrm{~cm}$ depth & 3 August & Homogenized & 3 August - \\
\hline UB-I & Burrow-lining sediment harvested $>20 \mathrm{~cm}$ & 2018 & and cultured & 13 September \\
\hline UB-Nex & $\begin{array}{l}\text { Sediment below sediment surface, above } 1 \mathrm{~m} \text {, and } 4-8 \mathrm{~cm} \\
\text { away from any burrow structure }\end{array}$ & & $\begin{array}{l}\text { in an aquarium } \\
\text { containing }\end{array}$ & 2018 \\
\hline UB-Bel & Sediment below $1 \mathrm{~m}$ depth & & aerated & \\
\hline UB-Sur & Surface sediment at least $5 \mathrm{~cm}$ away from any burrow openin & & seawater & \\
\hline \multicolumn{5}{|c|}{ Microbial community analysis for the digestive system of Upogebia and its commensal clam } \\
\hline UGM & Tissue dissected from the gastric mill of Upogebia & 19 June, & Frozen at $-20^{\circ} \mathrm{C}$ & 19 June, \\
\hline UHG & Tissue dissected from the mid and hind gut of Upogebia & 20 July, and & for fixing and & 20 July, and \\
\hline NDO & Tissue dissected from the digestive organ of Neaeromya & $\begin{array}{l}27 \text { September } \\
2018\end{array}$ & $\begin{array}{l}\text { then }-50^{\circ} \mathrm{C} \text { for } \\
\text { storage }\end{array}$ & $\begin{array}{l}\text { 27 September } \\
2018\end{array}$ \\
\hline
\end{tabular}

in diameter and $1 \mathrm{~cm}$ deep, were removed using cutoff $1 \mathrm{cc}$ syringes, transferred to $50 \mathrm{ml}$ centrifuge tubes (VWR), fixed with 1:1 ethanol:phosphate-buffered saline solution, and stored at $-20^{\circ} \mathrm{C}$ until further processing for CARD-FISH analysis (see Section 2.3). On the second sampling trip (3 August 2018), greater quantities of burrow lining sediments were dissected from extruded cores and transferred to $500 \mathrm{ml}$ containers labeled according to their depth-associated 'U' or 'I' positions, i.e. UB-U and UB-I, respectively, (Fig. 1a, Table 1). Sediment samples adjacent to burrow structures, but $4-8 \mathrm{~cm}$ apart from burrow linings, were also recovered and designated 'UB-Nex.' Anoxic sediments collected from below maximum burrow depths $(0.7 \mathrm{~m})$ were designated 'UB-Bel.' Separate surface sediments collected without the corer from the Idaho Flat, that were at least $5 \mathrm{~cm}$ from any burrow opening, were labeled 'UB-Sur.' These samples were stored at $5^{\circ} \mathrm{C}$ during transportation and further subsampled in the laboratory as described below (Section 2.2).

We collected reproductive-sized shrimp to recover Upogebia gastric mills (UGMs) (Fig. 1b), mid plus hind guts (UHG) (Fig. 1b), and Neaeromya rugifera digestive organs (NDO) on 3 occasions (Table 1). $N$. rugifera clams live on $U$. pugettensis pleopods and thus can only feed within the U. pugettensis burrow and only in concert with the activities of their shrimp hosts (Li et al. 2012). Four female and 2 male $U$. pugettensis were collected from the mud flat, held in clean seawater briefly to remove adhering sediments, and then frozen to fix all commensal species in place. Within $72 \mathrm{~h}$, these specimens were thawed, followed by dissection of the gastric mill plus mid and hind gut contents. Mid and hind gut contents were placed into $2 \mathrm{ml}$ vials and refrozen. The stomachs of the 3 largest undamaged Neaeromya associated with the collected shrimp were also removed and refrozen in $2 \mathrm{ml}$ vials. The dissected samples were frozen at $-20^{\circ} \mathrm{C}$ within $2 \mathrm{~h}$ of initial thawing, stored at $-20^{\circ} \mathrm{C}$ for $24-96 \mathrm{~h}$, and then transferred to $-50^{\circ} \mathrm{C}$ until initiation of DNA extractions. For these extractions, individual samples were pooled into combined UGM, UHG, and NDO samples and then divided into 2 replicates to reduce the effects of individual variation.

\subsection{Sediment cultures}

UB-U, UB-I, UB-Nex, UB-Bel, and UB-Sur samples were homogenized under a flow of nitrogen in the laboratory, on the day of collection, within their initial $500 \mathrm{ml}$ sample containers. One $\mathrm{ml}$ aliquots were then removed for DNA extraction and subsequent 16S rRNA gene sequencing (Fig. 1a). The remaining samples were divided into triplicate $50 \mathrm{ml}$ centrifuge tubes. These tubes of each sediment type were cultured upright, submerged, and open at $20^{\circ} \mathrm{C}$ for $40 \mathrm{~d}$ in a $38 \mathrm{l}$ aquarium filled with aerated Yaquina Bay seawater. After microelectrode profiling (see Section 2.4), $1 \mathrm{~cm}$ long sub-core samples were collected from the incubated sediment using cut-off $0.5 \mathrm{~cm}$ diameter syringes. The extruded sediment plugs were washed gently to reduce the volume of fine particles, and CB were then separated from the sediment matrix using fine glass hooks (Malkin et al. 2014). Unwashed sed- 


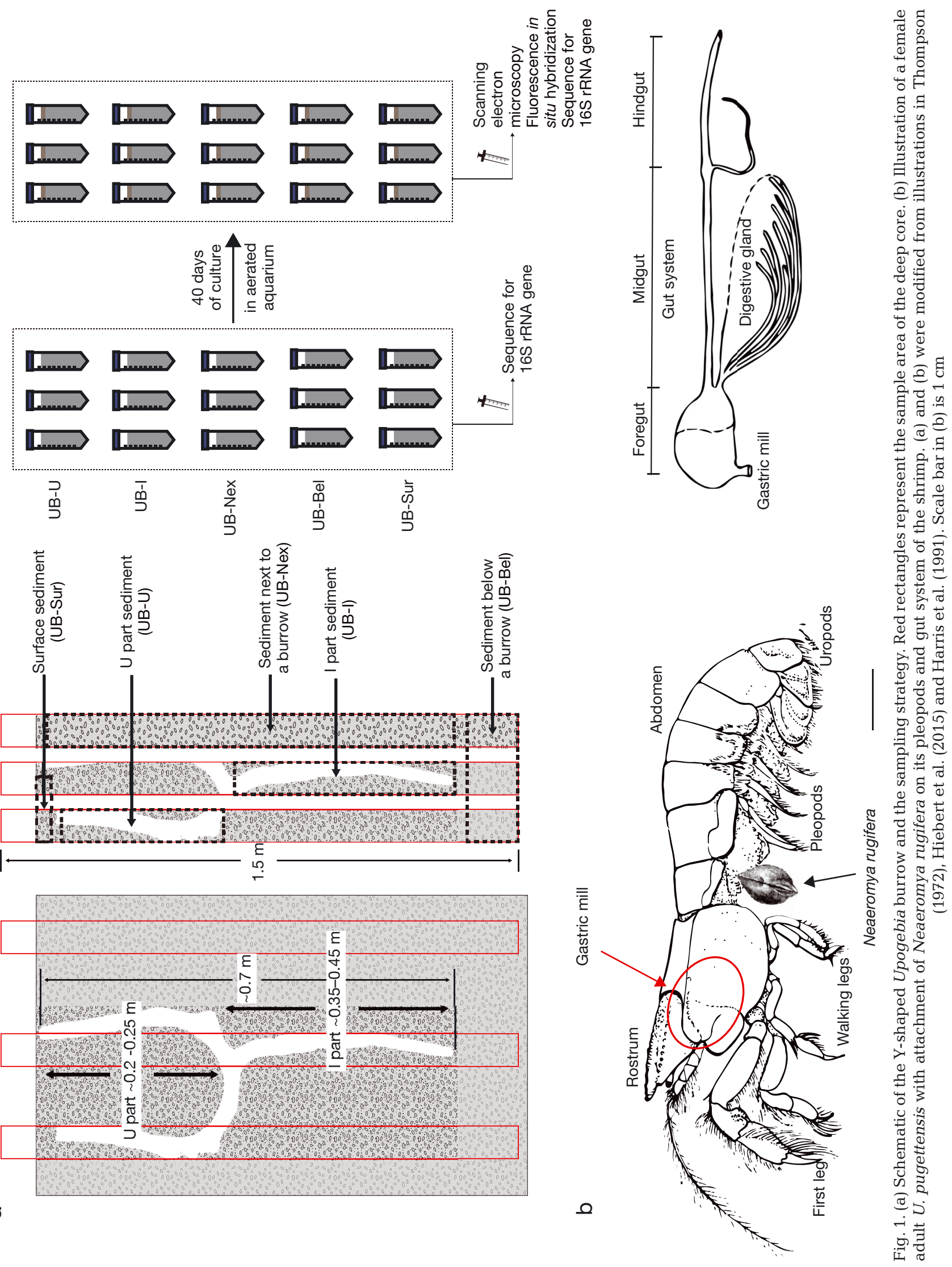


iment plugs and separated filaments were frozen or fixed for subsequent phylogenetic and microscopic characterizations.

\subsection{CARD-FISH}

CB were verified in sediments by CARD-FISH using a Desulfobulbaceae-specific oligonucleotide probe (DSB706; 5'-ACC CGT ATT CCT CCC GAT-3') modified with horseradish peroxidase. Two types of samples were hybridized: (1) fixed UB-S sediment and (2) bacterial filaments extracted from UB-U, UB-I, UBNex, UB-Bel, and UB-Sur sediment after $40 \mathrm{~d}$ of cultivation. The fixed sediment samples were first gently shaken to produce a slurry, and $100 \mu l$ of the mixture were then pipetted onto polycarbonate membrane filters ( $0.2 \mu \mathrm{m}$ pore size). The extracted bacterial filaments were retained on the same type of polycarbonate membrane filter and then gently washed 3 times with deionized water. Filters with sediments or bacterial filaments were cut into smaller pieces $\left(\sim 1 \mathrm{~cm}^{2}\right)$ and immobilized onto glass slides using $0.2 \%$ agarose.

The immobilized samples were air-dried and then dehydrated in $90 \%$ ethanol for 1 min. Dehydrated samples were sequentially permeabilized by $10 \mathrm{mg}$ $\mathrm{ml}^{-1}$ of lysozyme $\left(2 \mathrm{~h}\right.$ at $\left.37^{\circ} \mathrm{C}\right)$ and achromopeptidase $\left(1 \mathrm{~h}\right.$ at $\left.37^{\circ} \mathrm{C}\right)$. After permeabilization, endogenous peroxidases were inactivated by incubation in $\mathrm{H}_{2} \mathrm{O}_{2}$ $(0.15 \%$ in methanol) for $30 \mathrm{~min}$ at room temperature $\left(\sim 25^{\circ} \mathrm{C}\right)$. The hybridization process was performed in standard hybridization buffer (Wendeberg 2010) at $46^{\circ} \mathrm{C}$ with $45 \%$ formamide for $7 \mathrm{~h}$. Catalyzed reporter deposition was performed using Alexa Fluro 488 or Alexa Fluro 555 tyramides reagent (ThermoFisher). Catalyzed reporter deposition samples were then examined under a confocal laser scanning microscope (CLSM) (LSM 780, Zeiss).

\subsection{Chemical gradient profiling}

Vertical profiles of the cultured sediment samples were measured on Days 20 and 40 of cultivation using commercial microelectrodes (tip size $=100 \mu \mathrm{m}$, Unisense) operated with a field multimeter and positioned with a micromanipulator. Profiles of oxygen and $\mathrm{H}_{2} \mathrm{~S}$ and the $\mathrm{pH}$ of pore water from cultured sediments were measured to provide signature geochemical evidence of any CB activity (Malkin et al. 2014). The calibration and profiling of $\mathrm{pH}_{1} \mathrm{H}_{2} \mathrm{~S}$, and $\mathrm{O}_{2}$ microelectrodes were performed as described by Li et al. (2020).

\subsection{SEM}

Specimens for SEM were prepared by separating bacterial filaments from the cultured sediment samples as described in Section 2.3. Separated filaments were transferred to polycarbonate membrane filters ( $0.2 \mu \mathrm{m}$ pore size) and washed with deionized water. Washed specimens were then dehydrated in a graded series of ethanol from 10 to $100 \%$ and critical point dried under $\mathrm{CO}_{2}$ in a Critical Point Dryer (EMS 850, Electron Microscopy Sciences). Samples were then coated with gold and palladium using a sputter coater (Cressington 108, Cressington Scientific Instruments) and observed using an SEM (FEI QUANTA 600F, Thermo Scientific) at 5-15 kV. The SEM was also equipped to allow elemental spectra analysis by X-ray energy dispersive spectrometry (EDS).

\subsection{Bacterial community characterizations}

DNA extraction for 16S rRNA gene sequencing was performed on the uppermost $1 \mathrm{~cm}$ of sediment from UB-U, UB-I, UB-Nex, UB-Bel, and UB-Sur samples collected after $40 \mathrm{~d}$ of cultivation. DNA extractions were also performed on the initial homogenized aliquots of these sediments, and on pooled UGM, UHG, and NDO samples. DNeasy PowerSoil DNA extraction kits (Qiagen) that utilize beads to break down bacterial cells were used to extract the genomic DNA from all samples described above. We also enhanced the cell lysis by adding 10 freezethaw cycles prior to the use of the DNeasy kit. The V3/V4 regions of bacterial 16S rRNA genes were amplified by PCR with primers $357 \mathrm{wF}$ (5'-CCT ACG GGN GGC WGC AG-3') and 785R (5'-GAC TAC HVG GGT ATC TAA TCC-3'). Amplification and sequencing of DNA (Illumina MiSeq Reagent Kit v3, $2 \times 250 \mathrm{bp}$ ) were performed by the Center of Genome Research and Biocomputing at Oregon State University. Sequences were first processed using the DADA2 pipeline (Callahan et al. 2016) and aligned to the Silva SSU Ref NR database (v.132) in R or the Quantitative Insights into Microbial Ecology Version 2 (QIIME2) (Bolyen et al. 2019). Non-bacterial sequences were then removed.

Statistical analyses of alpha and beta diversity were conducted in QIIME2 by using the built-in core metric phylogenetic method. To include most of our samples, we chose a sequencing depth of 2000 reads for rarefaction. Rarefied samples were only used to calculate alpha and beta diversity. Different alpha diversity indexes were illustrated by 
using the R package 'phyloseq' (v.1.30.0) (McMurdie \& Holmes 2013). Statistical significance of the bacterial community differences was estimated by permutational multivariate ANOVA (PERMANOVA) in beta diversity.

We then analyzed the core microbiome across all sample types: Upogebia, Neaeromya, and sediment (UNS) by comparing all obtained sequences in 'Venny' (Oliveros 2015). Structure of the microbiome and difference in abundance for each taxon across all of our sample types were analyzed by using the R packages 'MetacodeR' and 'Taxa' (Foster et al. 2017, 2018). To test for taxa in the core microbiome having significantly different abundances across sample types, we performed a Wilcoxon rank sum test with a false discovery rate correction for multiple tests on the median abundance for each taxon. For all statistical analyses in the present study, a p-value $<0.05$ was considered significant.
Sequences from this study were deposited in the GenBank Sequence Read Archive under accession numbers PRJNA549311 and PRJNA549312 for sediment and shrimp/bivalve microbiome samples, respectively.

\section{RESULTS}

\subsection{CB within sediments associated with Upogebia pugettensis burrows}

The initial UB-S samples of $U$. pugettensis burrow linings recovered for this study were composed of a mud-clay and silt substrate and appeared to be cemented by shrimp secretions and mineral precipitates, as suggested by previous observations (Thompson \& Pritchard 1969). These samples seemed a likely substrate for finding $C B$, but the agglutinated struc-
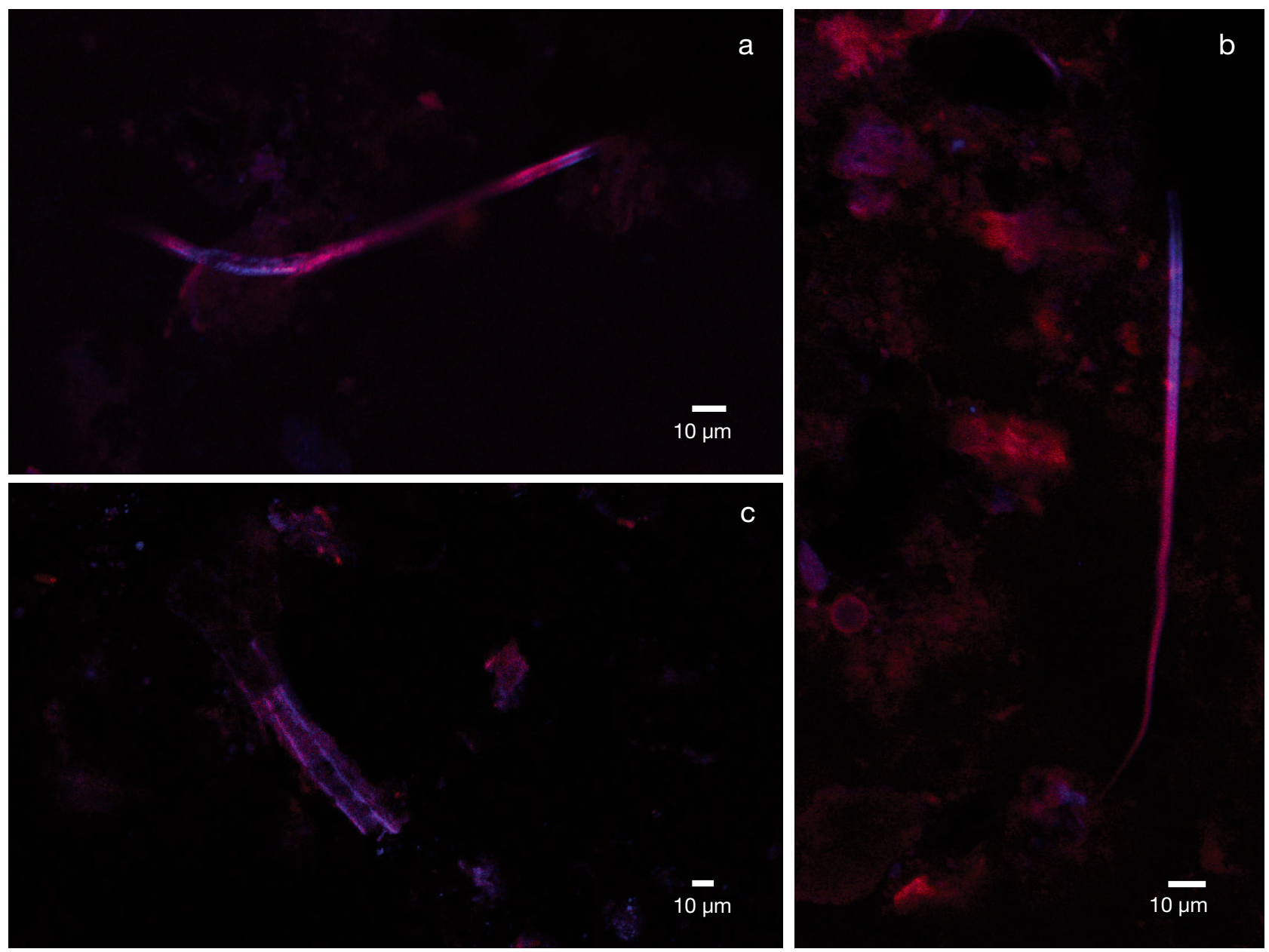

Fig. 2. $(\mathrm{a}-\mathrm{c})$ Confocal microscope images illustrating cable bacteria filaments in Upogebia burrow-lining sediment collected on 8 June 2018 (UB-S). DSB 706 probe + Alexa Fluro 555, red and DAPI, blue 
ture made the direct isolation and picking of the $\mathrm{CB}$ filaments from lining sediments difficult. Despite these challenges, when the fixed samples were hybridized with DSB706 probe, CB filaments (generally $<200 \mu \mathrm{m}$ in length) were observed when examined by CLSM (Fig. 2). Cell aggregates that reacted positively with the DSB 706 probe were observed as well, suggesting that other members within the family of Desulfobulbaceae were active within the burrow-lining sediment. These initial observations prompted continuing studies with incubated sediment samples.

When first homogenized, incubated UB-U, UB-I, UB-Nex, UB-Bel, and UB-Sur sediments appeared grey and lacked sulfidic odors. Upon culture in open tubes, we observed (1) the formation of suboxic zones where sulfide and oxygen were below detection, and (2) the appearance of a subsurface $\mathrm{pH}$ maximum, both of which are geochemical hallmarks of electrogenic sulfur oxidation catalyzed by CB (Pfeffer et al. 2012), in the UB-U, UB-I, and UB-Bel samples after $20 \mathrm{~d}$ of incubation (Fig. 3). In contrast, no dissolved sulfide was detected in UB-Nex samples (profiles to $12 \mathrm{~mm}$ ), and sulfide concentrations in UBSur sediments were approximately 10 times greater than in the incubated burrow-lining sediments (Fig. 3). In addition, we did not detect a distinct suboxic zone in UB-Sur samples by Day 20 of incubation. Another observation was that red-brown mineral layers formed in the top centimeter of UB-U and UB-I samples within $20 \mathrm{~d}$ of incubation. The appearance of these layers was consistent with enrichments of iron oxide-hydroxides as is typically observed in Upogebia burrow linings in situ (Thompson \& Pritchard 1969, this study).

By Day 40 of incubation, suboxic zones spanning 2-8 $\mathrm{mm}$ of sediment developed in all incubated sediments (Fig. 3). Separation of the oxygen-penetration depth and the sulfide-bearing depth in all sediments increased from conditions on Day 20 in all but the UB-U samples. Differences between high and low $\mathrm{pH}$ extremes diminished, and the oxygen concentration near the sediment-water interface decreased in UB-U and UB-I samples, suggesting that the activity of electrogenic sulfur oxidation was declining.

\subsection{Microscopic identification of $\mathrm{CB}$ from cultured sediments}

Filamentous biomass was extracted from all 5 cultured sediment samples (UB-U, UB-I, UB-Nex,
UB-Bel, and UB-Sur) after $40 \mathrm{~d}$ of culture. Extracted filaments bound to the DSB 706 probe, showing positive fluorescence (Fig. 4a). Individual filament lengths from 500 to over $1000 \mu \mathrm{m}$ were visualized. Many of the extracted filaments examined by SEM were coated with irregular particles (Fig. 4b). EDS analysis revealed that these particles consisted of primarily silicon $(\mathrm{Si})$, aluminum $(\mathrm{Al})$, magnesium $(\mathrm{Mg})$, and iron $(\mathrm{Fe})$, a similar elemental composition to authigenic clays (see Fig. S1 in the Supplement at www.int-res.com/articles/suppl/ m648p079_supp.pdf). Such clays have been proposed to adhere to filaments because of secreted extracellular polymeric substances produced by CB (Geerlings et al. 2019). Naked filaments resembling CB were also observed (Fig. 4b,c). Most CB observed in sediments from a variety of sites worldwide have 15-71 longitudinal ridges and are greater than $1 \mu \mathrm{m}$ in diameter. The filaments from the incubated sediments had 8 to 10 ridges and were less than $1 \mu \mathrm{m}$ in diameter, consistent with $\mathrm{CB}$ filaments that we found previously in Yaquina Bay sediments (Li et al. 2020). These CB may thus belong to a different linage or growth stage compared to those reported previously (Trojan et al. 2016).

\subsection{Diversity of bacterial communities in sediments, shrimp, and Neaeromya}

After quality filtering, the total number of reads in 16 samples (10 sediments: Day 0 and Day 40; 4 shrimp: hind gut and gastric mill; and 2 Neaeromya: stomachs) prepared for assessing relative bacterial abundances was 1359069 , and the total number of detected taxa was 25902 , of which 25053 were bacterial. Reads were abundant in sediment and Neaeromya samples (from 60744 to 174403 per sample) and varied markedly in $U$. pugettensis samples between replicates (from 525 to 23098 ). To include most of our samples, we chose a sequencing depth of 2000 reads for rarefaction, and we observed plateaus in the Shannon index for all samples, suggesting that the sampling size was large enough to cover the diversity of sampled bacterial communities (Fig. S2). Alpha diversity was highest in sediment samples, followed by the Neaeromya samples (Fig. S3). Within sediment samples, UB-Sur possessed the highest diversity and UB-Bel had the lowest diversity. Within shrimp samples, UHG materials had slightly more diverse microbial communities compared to UGM materials. 

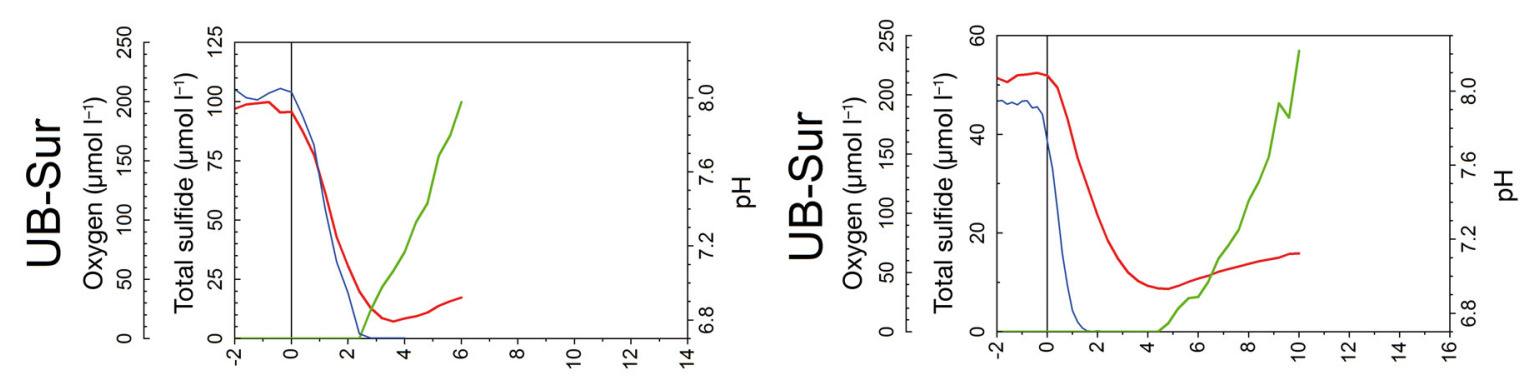

3.

岁岕。

용

8

5)

这要

눙

웅응

월
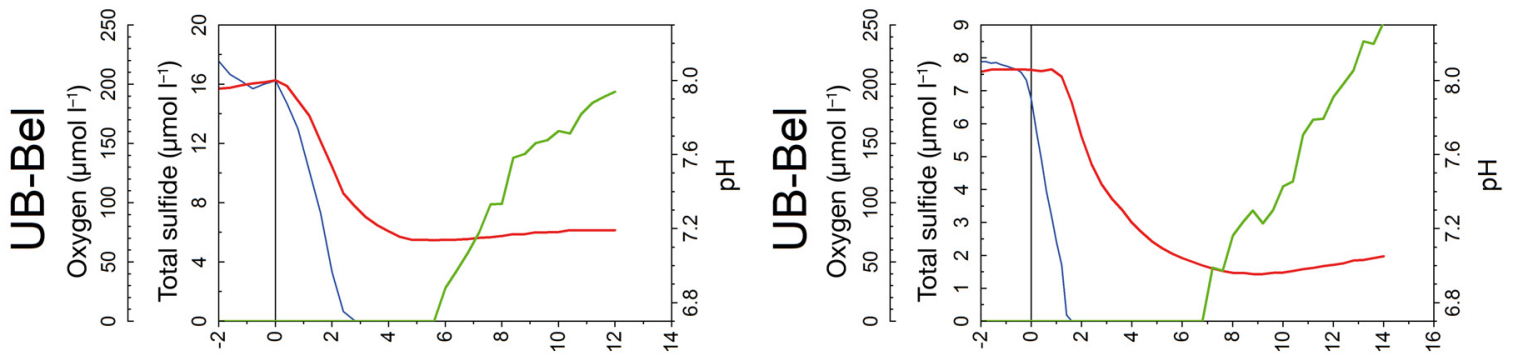

क 35

일

प्द व

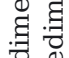

D

리 잉

콩 요유

氙离

क्ष
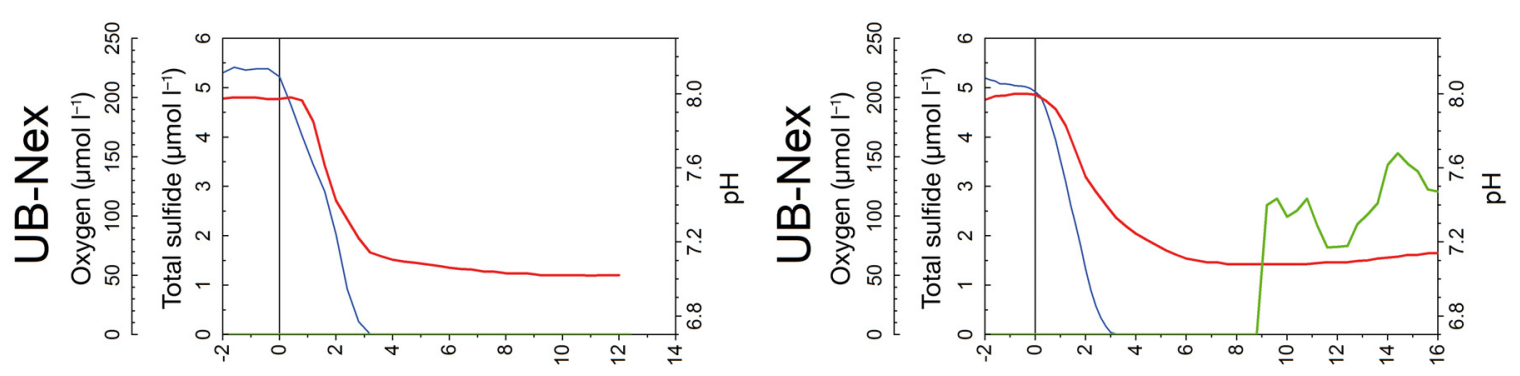

氙已。

ช

焉家完

중 ब

등ํㅇ

宇包

范

종
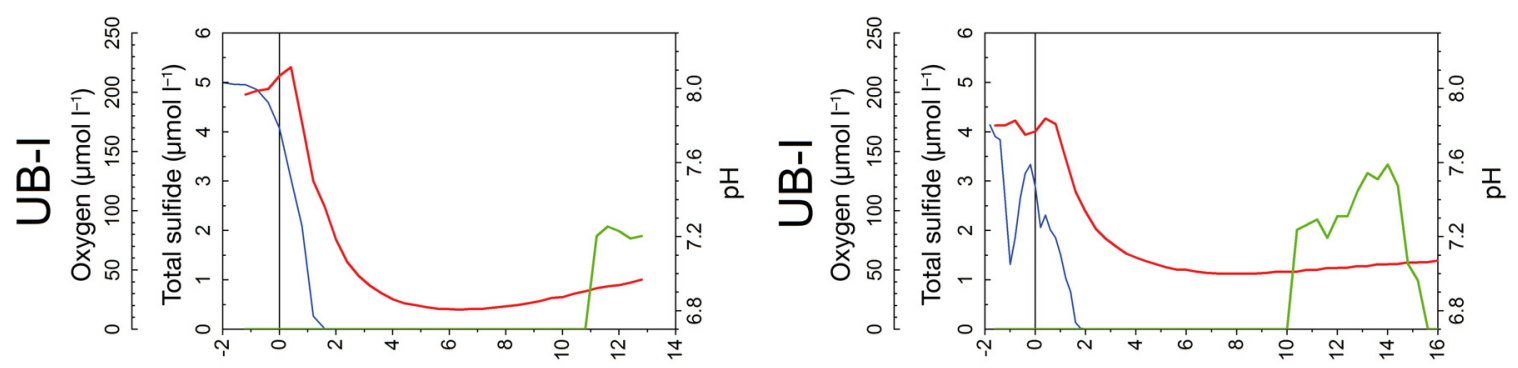

资

क्ष

를 뭉 뭉

表范

त्रें ำ

प्व

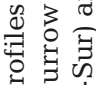

อ. อ่

동 五

웡

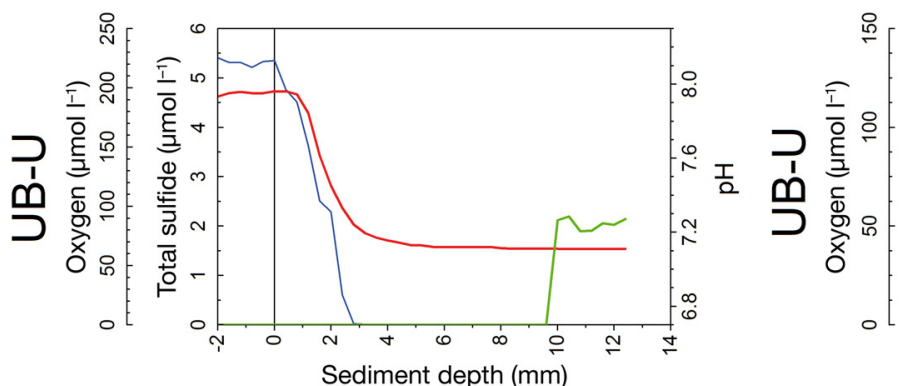

Day 20

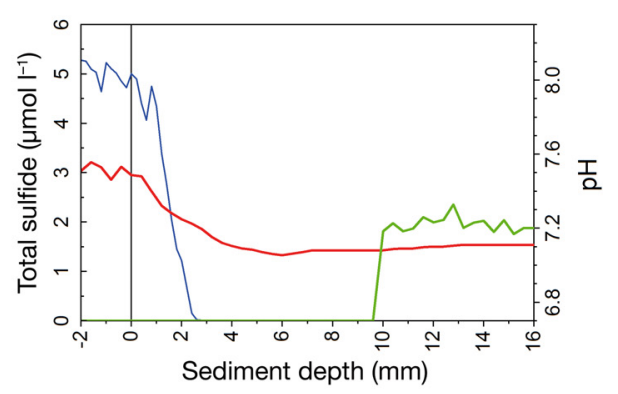

Day 40

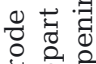

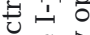

일

월

명

究: 寻

氙苟

。․ 명

थ 

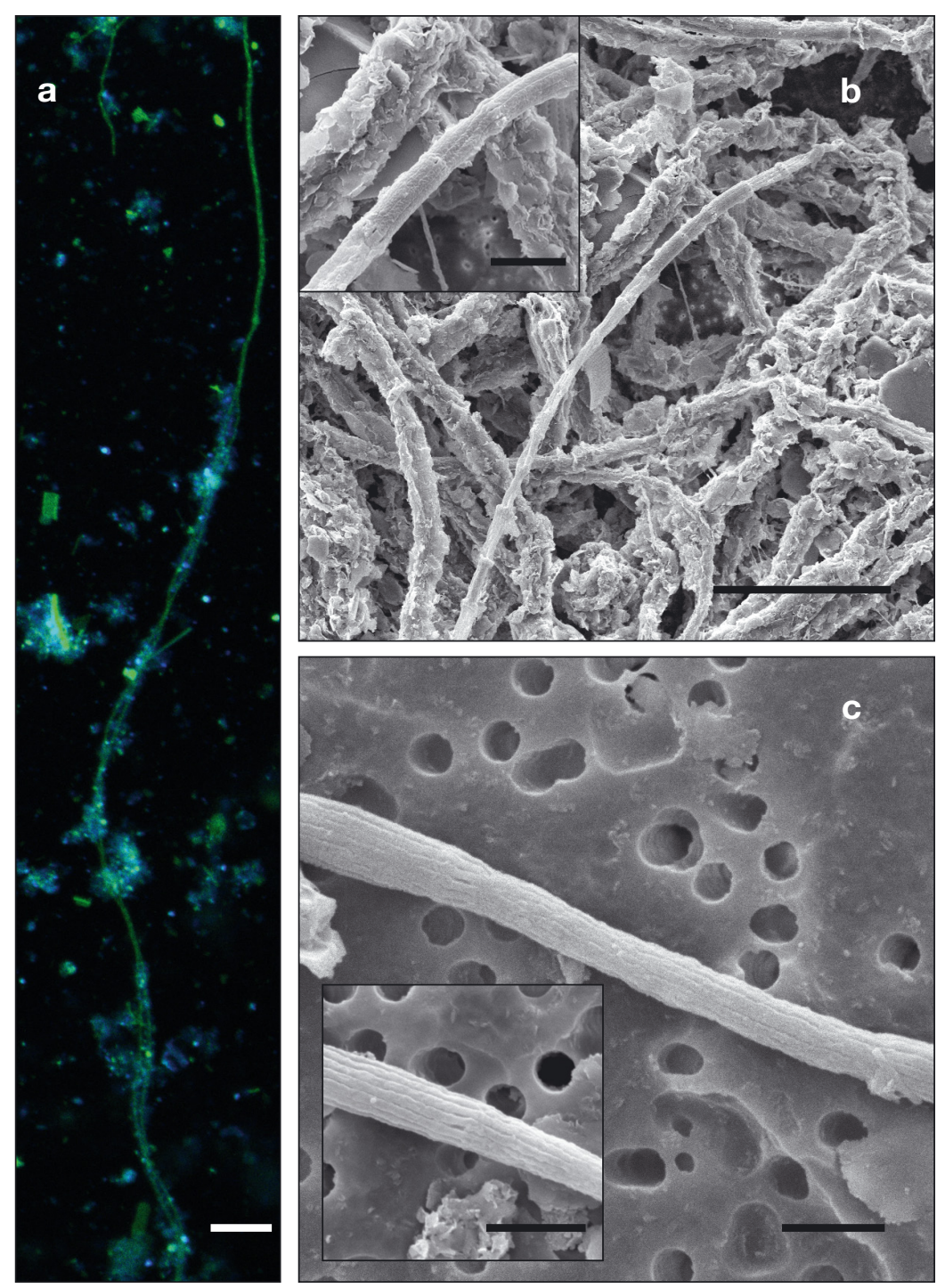

Fig. 4. Cable bacteria filaments extracted from sediment samples after $40 \mathrm{~d}$ of cultivation. (a) Filaments belonging to Desulfobulbaceae identified using CARDFISH (DSB 706 probe + Alexa Fluor 488, green and DAPI, blue). (b,c) Filaments of cable bacteria under SEM. Scale bar in Fig. 4a, $20 \mu \mathrm{m}$; scale bar in Fig. 4b, $10 \mu \mathrm{m}$ (in Fig. 4b inset, $2 \mu \mathrm{m}$ ); scale bar in Fig. 4c, $1 \mu \mathrm{m}$ (in Fig. 4c inset, $1 \mu \mathrm{m}$ )

A principal coordinate analysis of beta diversity indicated that the bacterial communities clustered according to sample origin (Fig. S4). All sediment samples clustered together, while shrimp and Neaeromya samples separated. PERMANOVA tests suggested that the shrimp gut samples were significantly different from all sediment samples (including both Day 0 and Day 40 samples) $(\mathrm{p}<0.05)$ but that differences between Neaeromya and shrimp samples were insignificant $(\mathrm{p}=$ 0.104, Table 2). The difference between Neaeromya and sediment samples on Day 40 was insignificant ( $p=$ 0.056).

\subsection{Composition of bacterial communities in sediments, shrimp, and Neaeromya}

Sediment samples collected before the start of incubations (Day 0) are considered to be representative of in situ communities before cultivation. Proteobacteria were the predominant phylum across all sediment locations (Fig. 5a, Table S1), ranging from 44.5 to $47.5 \%$. Bacteroidetes was the second most abundant phylum, ranging from 15 to $25.3 \%$. Desulfobulbaceae (5.7 to $8.0 \%$ ) and Desulfobacteraceae (4.7 to $8.9 \%$ ) in Proteobacteria were dominant, and Flavobacteriaceae (7.9 to $16.0 \%)$ and Bacteroidetes BD2-2 (2.3 to $2.7 \%$ ) in Bacteroidetes were prevalent at the family level. Taxa from the candidate genus of $\mathrm{CB}$, Candidatus

Table 2. Statistical analysis of 16S rRNA gene libraries in the invertebrate microbiomes and sediment microbial communities. Pairwise PERMANOVA comparison between microbial communities. D0: Day 0; D40: Day 40

\begin{tabular}{|lccc|}
\hline Group 1 & Group 2 & Sample size & $\mathrm{p}$ \\
\hline Neaeromya & Upogebia & 5 & 0.104 \\
& Sediment D0 & 7 & 0.043 \\
& Sediment D40 & 7 & 0.056 \\
Upogebia & Sediment D0 & 8 & 0.015 \\
& Sediment D40 & 8 & 0.018 \\
Sediment D0 & Sediment D40 & 10 & 0.111 \\
\hline
\end{tabular}

Electrothrix, were present in all sediments before cultivation except the UB-Bel samples. Samples from sediments exposed in situ to oxygen through burrows or at the sediment surface contained higher proportions of Candidatus Electrothrix (Fig. 5b).

After $40 \mathrm{~d}$ of cultivation, the phylogenetic diversity of sediment microbial communities remained relatively unchanged compared to Day 0 samples (Figs. S3 \& S4). Bacteroidetes that are specialized in degrading high molecular weight compounds such as algal materials decreased (Fernández-Gómez et al. 2013), possibly reflecting changes in composition of degradable organic materials. Proteobacteria 

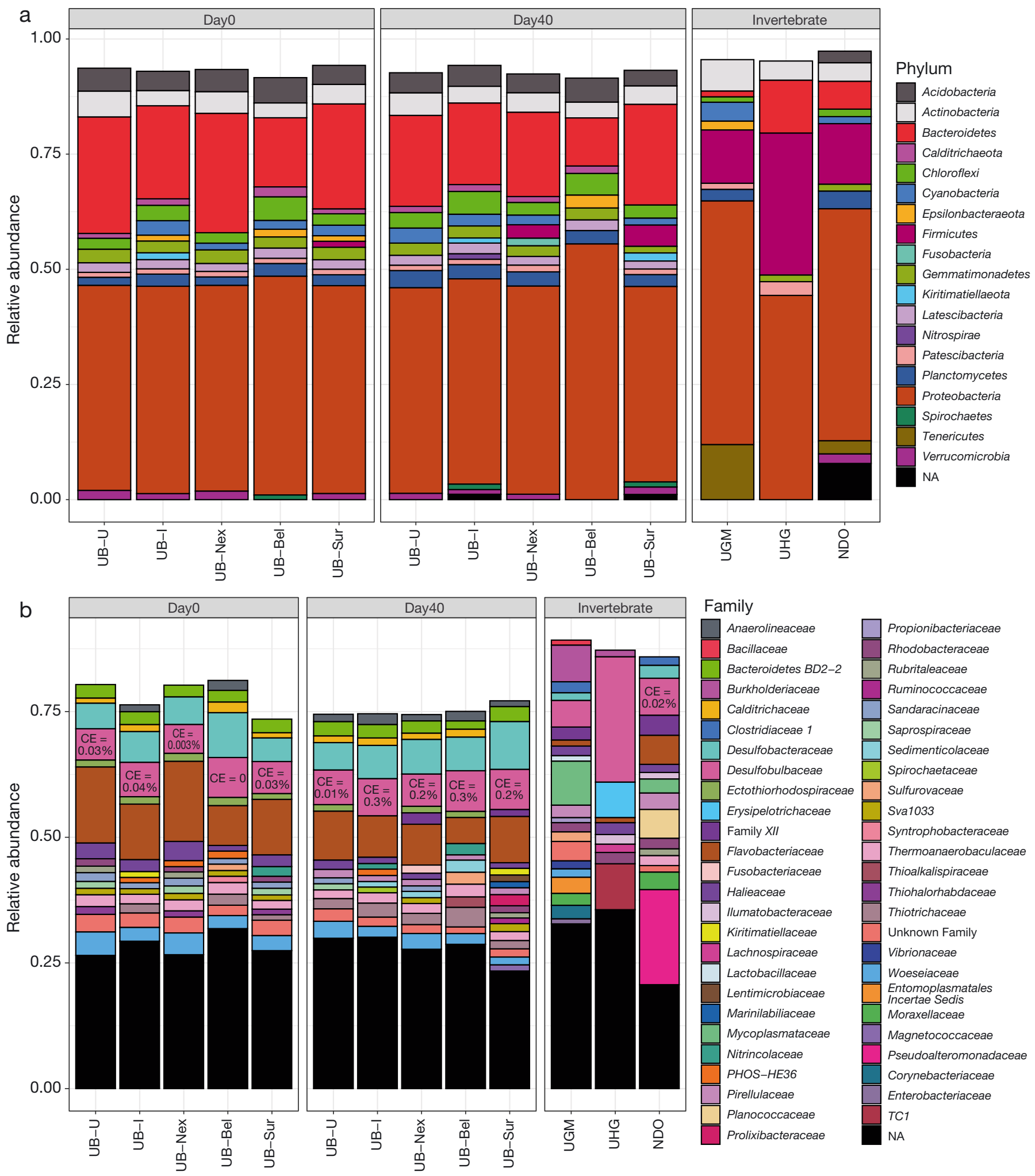

Fig. 5. Relative abundances of (a) phyla and (b) families comprising $>1 \%$ of bacterial communities. UB-U: sediment linings in Upart of the Upogebia burrow, UB-I: sediment linings in I-part of the burrow, UB-Nex: anoxic sediment next to the burrow, UB-Bel: anoxic sediment below the burrow, UB-Sur, surface sediment away from burrow openings, UHG: Upogebia hind gut, UGM: Upogebia gastric mill, NDO: Neaeromya digestive organ; CE: a cable bacteria genus, Candidatus Electrothrix. Unknown Family is families within orders of Gammaproteobacteria Incertae Sedis or Deltaproteobacteria Incertae Sedis that have been recognized by the SILVA 132 database. NA stands for those that have not been recognized by the database. See Fig. 1 for an illustration of the sampling scheme in relationship to burrow structures 
remained the most abundant phylum, ranging from 42.4 to $55.5 \%$. At the family level, Flavobacteriaceae decreased significantly compared to Day $0(\mathrm{p}<0.05)$. Desulfobulbaceae increased slightly in all samples. Within this increase, the marine CB genus Candidatus Electrothrix was observed in all sediment samples with relative abundances based on reads from 0.01 to $0.3 \%$ (Fig. 5a).

The compositions of bacterial communities in shrimp and Neaeromya samples were different from the sediment (Fig. 5a). Proteobacteria was the most abundant phylum, ranging from 44.3 to $52.8 \%$, followed by Firmicutes (11.7 to $30.8 \%$, Table S2). At the family level, Mycoplasmataceae, in the phylum Tenericutes, was dominant (8.8\%) in UGM samples. In UHG samples (Fig. 5b), Desulfobulbaceae was the most abundant family $(24.9 \%)$, mainly composed of a single genus (Desulfocapsa, 23.3\%). The family Pseudoalteromonadaceae (18.9\%) was dominant in NDO samples. CB were not found in UGM and UHG samples, while stomach samples of $N$. rugifera (NDO) included the marine $\mathrm{CB}$ genus Candidatus Electrothrix at $0.018 \%$ relative abundance.

When differences in abundance for each phylum are compared across all of our samples, the overall dominance of Proteobacteria is evident (Fig. 5). Acidobacteria, Bacteroidetes, Calditrichaeota, Chloroflexi, and Latescibacteria appear to be more pronounced in sediment extracts, while Firmicutes stand out in shrimp and Neaeromya samples. Tenericutes was found only in UGM and NDO samples.

\subsection{Similarity analysis between sediments, shrimp, and Neaeromya}

The exponentially increasing proportions of unidentified amplicon sequence variants (ASVs) with decreasing taxonomic level (Fig. S5a) reduced the number of overlapping taxa available for comparisons among samples. Therefore, similarity analyses among samples were limited to phylum, where nearly all taxa of all samples were identified. Proteobacteria was the dominant phylum in all sediment and Upogebia/Neaeromya samples, and Desulfobulbaceae was the dominant family within Proteobacteria in all samples. Proportions of the 16 most abundant phyla in Upogebia/Neaeromya samples were also closely correlated with Day 0 sediments (Fig. S5b). Among the correlations between bacterial communities in sediment and Upogebia/Neaeromya samples, UHG were reduced relative to UGM and NDO (Fig. S5b).

\subsection{Core microbiome between Upogebia, Neaeromya, and burrow sediments}

To investigate the potential trophic connection between $U$. pugettensis and the microbial communities of the sediment harboring their burrows, we identified the core microbiome between samples. We found that 41.4 and $39.5 \%$ of bacterial taxa in shrimp and Neaeromya, respectively, were found in the sediment. The UNS core group was composed of $181 \mathrm{ASVs}$ and represented only $0.7 \%$ of the total ASVs detected in all samples (Fig. 6a). However, these $181 \mathrm{ASVs}$ in total contributed $17.9 \%$ in relative abundance, suggesting that these taxa were important members of the bacterial community (Fig. 6b). Despite the low numbers of ASVs in the core microbiome, these data support the hypothesis that shrimp and Neaeromya share a large portion of their microbiome with the sediment, indicating ingestion of sediment microbiota by these organisms.

Within the UNS core microbiome, we observed differences in the relative abundances of taxa across sample types. Taxa in the phyla Acidobacteria, Bacteroidetes, Chloroflexi, Cyanobacteria, and Latescibacteria and in the order Deltaproteobacteria were more pronounced in sediment than in shrimp. Taxa in the phyla Firmicutes and Patescibacteria and in the order Alphaproteobacteria were more enriched in shrimp than in sediment. Taxa in the Cyanobacteria and Laterscibacteria were more abundant in sediment than in Neaeromya. Taxa in the phyla Acidobacteria, Firmicutes, Halanaerobiaeota, and Planctomycetes and in the orders Actinobacteria and Alphaproteobacteria were more prevalent in Neaeromya than in sediment. No difference was observed when comparing the abundance of each taxon in the UNS core microbiome between shrimp and bivalves.

It should be noted that certain highly abundant taxa were identified outside of the core microbiome. For example, the dominant genera Desulfocapsa and Pseudoalteromonas were only found in shrimp and bivalves, respectively. The CB genus Candidatus Electrothrix was observed only in sediment and bivalve samples.

\subsection{Desulfobulbaceae phylogenetics}

Candidatus Electrothrix ASVs identified from UBU, UB-I, UB-Nex, UB-Bel, UB-Sur, and NDO samples clustered with putative $\mathrm{CB}$ sequences from marine sediments and within the marine genus of $\mathrm{CB}$ found 
previously in Yaquina Bay (Fig. S6). The most abundant Desulfobulbaceae ASVs in burrow sediments and the second most abundant Desulfobulbaceae ASV in UGM appeared to cluster with the marine genus and groundwater CB (Müller et al. 2020, Trojan et al. 2016). The major subset of Desulfobulbaceae identified in the UNS core microbiome did not cluster with either CB sequences or with those of Desulfobulbus. Instead, they appeared to group closer to the genera Desulfocapsa and Desulforhopalus.

\section{DISCUSSION}

\subsection{Opportunistic response of $C B$ in sediment bioturbated by Upogebia pugettensis}

The present study revealed the presence of CB in the lining and surrounding sediments of U. pugettensis burrows. The anoxic sediment below the burrows (UB-Bel) did not show any trace of CB before culture, but developed $\mathrm{CB}$ and their characteristic geochemi-

a

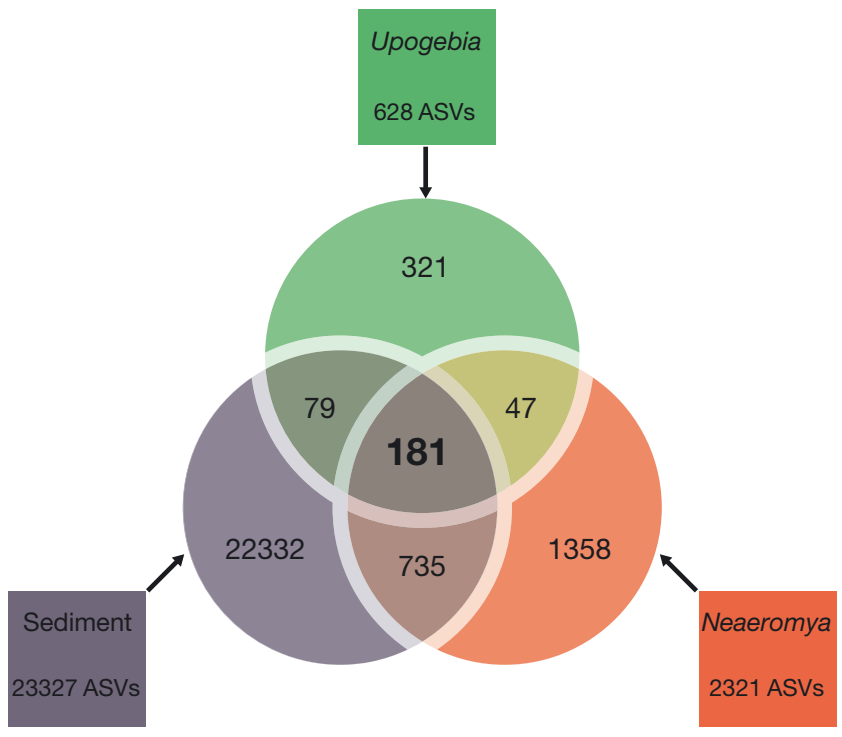

Fig. 6. (a) Venn diagram of the core microbiome across samples. A total of 181 amplicon sequence variants (ASVs) are shared by Upogebia, Neaeromya, and sediment. (b) Relative abundance of the core microbiome in each sample. (c) Differential heat tree illustrating the significant differences in abundance of each taxon within the core microbiome across Upogebia, Neaeromya, and sediment. Node sizes correspond to the number of ASVs observed within a given taxon. Colors represent the log fold difference of a given taxon's median relative abundance. D0: Day 0; D40: Day 40; other abbreviations as in Fig. 5

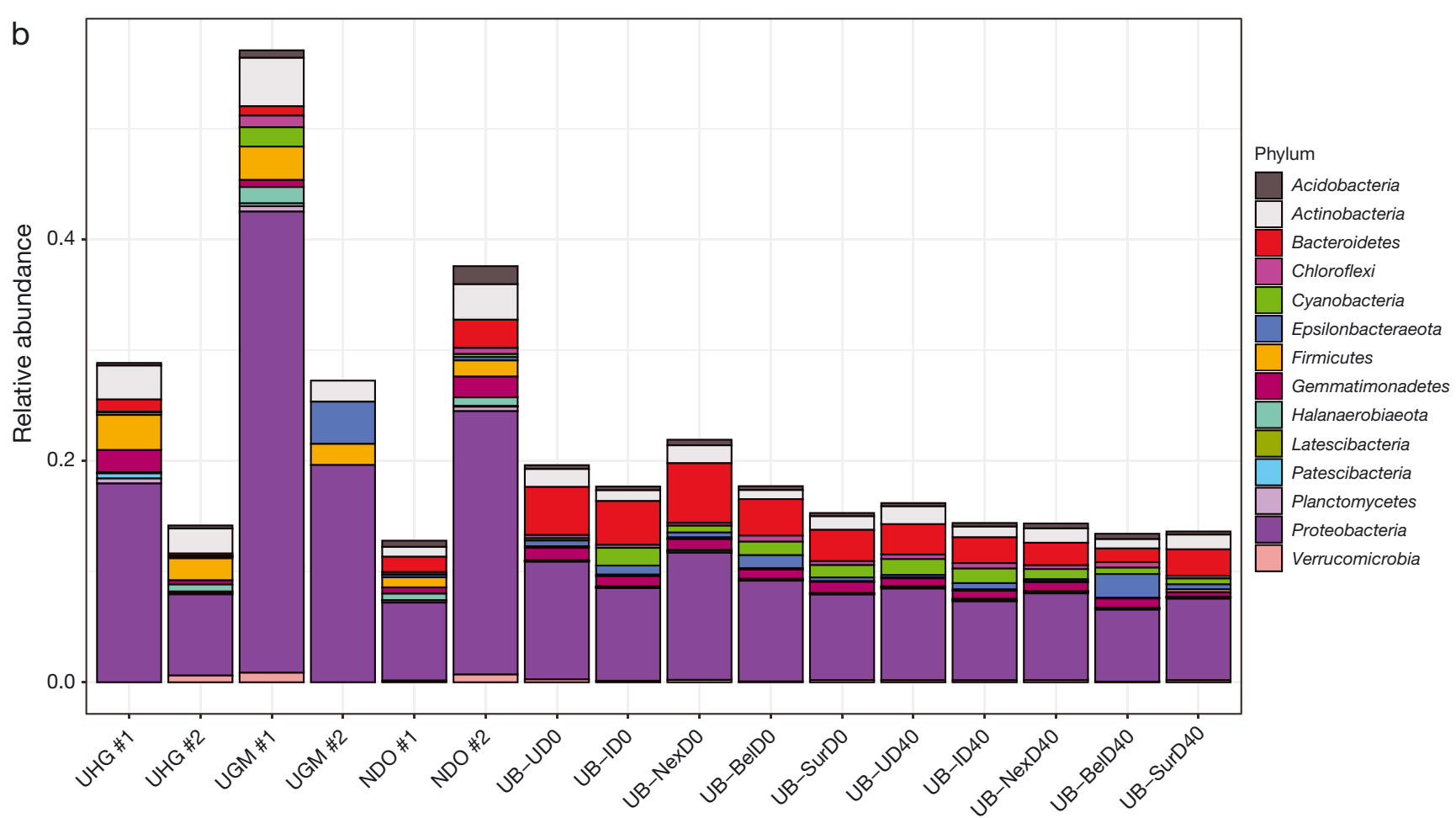

(continued on next page) 


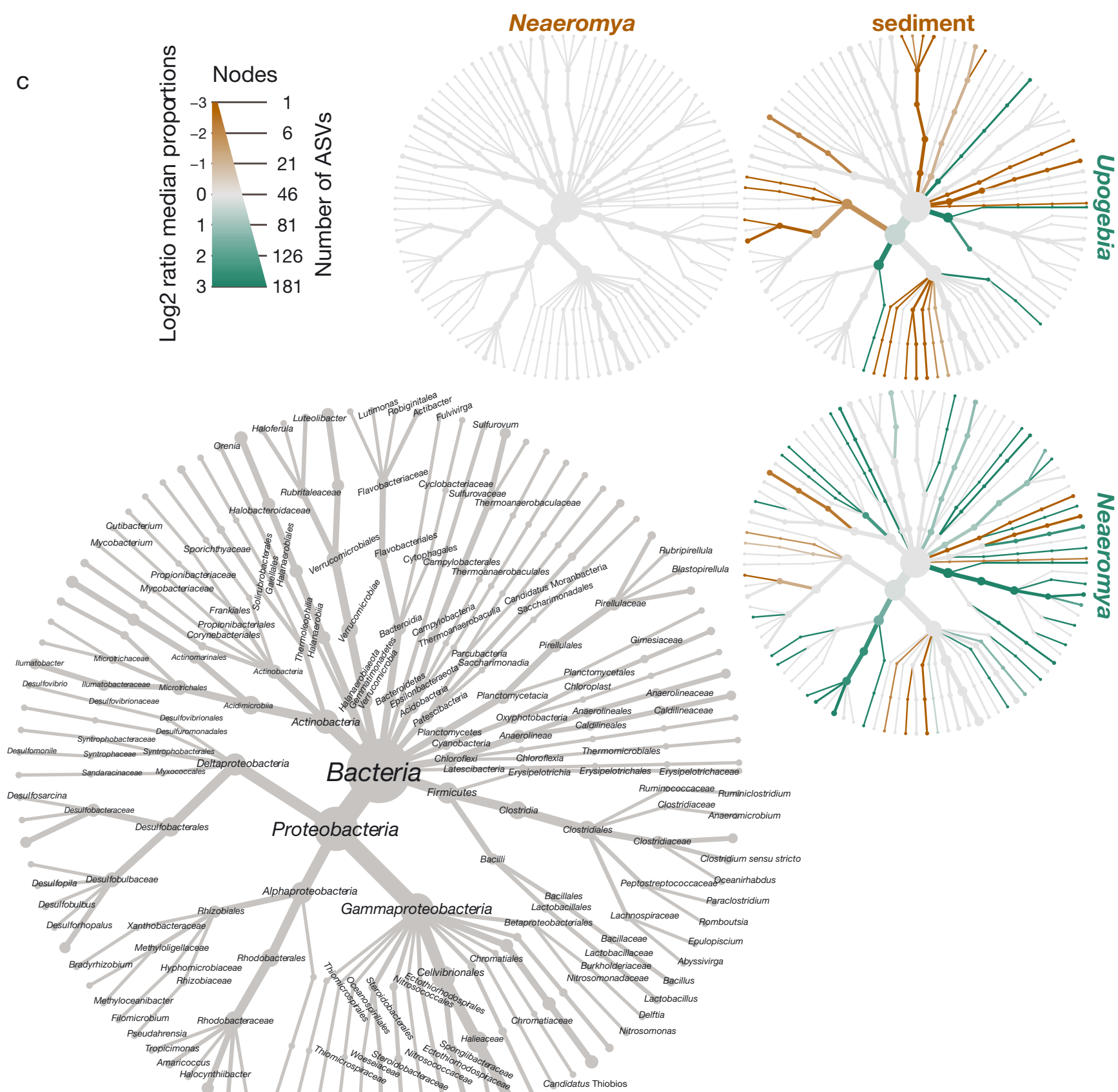

Fig. 6 (continued)

cal signatures after oxygen was introduced. These results corroborate previous reports of $\mathrm{CB}$ as opportunistic bacterial community members in intertidal mudflat sediments. CB are likely to become inactive when electron acceptor concentrations are low and grow when bioirrigation draws oxygen-saturated water to shrimp burrow linings. Thus, Upogebia burrow networks may create a favorable environment for $\mathrm{CB}$, thereby expanding the ecological options of CB (Aller et al. 2019).
In spite of these observations, a surprising result was that the sediment samples examined here contained relatively low abundances of the most commonly characterized marine CB genus Candidatus Electrothrix even after lab cultivation (Geelhoeld et al. 2020). Instead, we found dominant phylogenetic taxa $(>1 \%)$ that cluster similarly to both marine and groupwater CB. Whether these ASVs were from the filamentous bacteria visualized under SEM or by CARD-FISH, and whether these different but related 
taxa can all catalyze long-distance electrogenic sulfur oxidation, remain as questions for further detailed investigation.

\subsection{Core microbiome analysis indicates a trophic connection between $U$. pugettensis and sediment}

Despite their importance to the intertidal ecosystem, upogebiids, in particular U. pugettensis, are not well studied (Coelho et al. 2000). The diet of the shrimp and their feeding behavior while inhabiting their burrows remains elusive. The shrimp reside within their burrows for all of their lives after settling from their final pelagic larval stage (Chapman et al. 2012). The weak mouthparts, complex gastric sieving anatomy, complex digestive system, and denselysetose external anatomy restrict $U$. pugettensis to suspension feeding on fine particles (Powell 1974). Diet sources of these shrimp are thus limited to suspended particulate organic matter circulated through their burrows from the overlying waters during high tides, or suspended particulate organic materials from resuspensions of their burrow lining sediments (Thompson 1972, Kinoshita et al. 2003). Bosley et al. (2017) investigated potential diets of $U$. pugettensis by comparing fatty acid fractions and carbon:nitrogen stable isotope $\left(\delta^{13} \mathrm{C}\right.$ and $\left.\delta^{15} \mathrm{~N}\right)$ ratios in $U$. pugettensis and their potential food sources. Fatty acid compositions and stable isotope ratios in $U$. pugettensis tissues did not match closely with those from suspended sediment particulates nor from burrow lining organic matter (Bosley et al. 2017).

In the present study, the UNS core microbiome analysis and correlations in abundances at the phylum level indicate that $U$. pugettensis include major proportions of the burrow sediment microbial community within their gut microbiomes. This result provides evidence that bacterial biomass harvested from the burrow sediment lining is a major food source for $U$. pugettensis. In addition, the large overlapping portion of the Neaeromya microbiome and the sediment microbial community is further corroborative evidence indicating that $U$. pugettensis feed on sedimentary bacterial biomass. The commensal bivalve can only feed along with its active host. Beta diversity and median abundance in the core microbiome suggest that the shrimp samples do not differ significantly from the Neaeromya samples, indicating the potential similar origin of their microbiomes.

Differences between samples in the relative abundances of members of the core microbiome may indicate microorganisms that become established in a gut microenvironment after ingestion. For example, Firmicutes, in particular Bacilli and Clostridia, were more pronounced in Upogebia/Neaeromya compared to the sediment. Other enriched taxa within the core microbiome of Upogebia/Neaeromya were common members in the sediment microbial community, namely Patescibacteria and Planctomycetes (Fuerst \& Sagulenko 2011, Tian et al. 2020). Actinobacteria and Rhodobacterales, which were more pronounced in Neaeromya compared to the sediment, are known for their ability to degrade particulate organic matter (Pohlner et al. 2019, Puttaswamygowda et al. 2019). In concert, these data strongly corroborate that $U$. pugettensis food sources include the bacterial biomass in their burrow sediment (Powell 1974, Aller et al. 1983, Kinoshita 2002, Bosley et al. 2017).

\section{IMPLICATIONS}

The present study revealed that CB are present as members of microbial communities in the sediment linings of Upogebia pugettensis burrows from the mudflats of Yaquina Bay, Oregon, and that they grew in anoxic sediments collected from below or adjacent to shrimp burrows once oxygen was introduced. These observations expand our understanding of biogeochemical impacts of burrowing bioturbators on various intertidal environments. Burrows and tubes of many other mudflat invertebrates function similarly, introducing oxygenated seawater to the subsurface sediments. Oxygen may also be introduced to subsurface intertidal mudflat sediments through the rhizosphere of seagrass roots inducing electrogenic sulfur oxidation (Martin et al. 2019). Taken together, burrows and tubes of macrofauna combined with seagrass root systems create large extended surface areas conducive to $\mathrm{CB}$ activity and the proliferation of diverse microbial communities (Aller et al. 2019).

This study was conducted, in part, in response to efforts to understand all scales of ecosystem linkages to an ongoing collapse of $U$. pugettensis populations due to intense infestations by the introduced bopyrid isopod parasite, Orthione griffenis (Markham 2005), which infest only reproductive-size $U$. pugettensis (Dumbauld et al. 2011). Moreover, preliminary experiments, conducted outside of burrow galleries, reveal that host presence, sex, reproductive development, and molt development are insufficient conditions for O. griffenis settlement. Resolution of the energetics and trophic connections of $U$. pugettensis with their burrow linings and $O$. griffenis settlement may thus 
be critical for the management and conservation of this native mud shrimp.

Acknowledgements. This research was funded through grant N00014-17-1-2599 from the Office of Naval Research to C.E.R. We thank Dr. Hubert Müller from the University Duisburg-Essen for providing the partial 16s rRNA gene of the groundwater cable bacteria. We are grateful to Rogene Kasparek Thompson for her seminal work on Upogebia burrow ecology. We thank Cora Bobo-Shisler for collecting and delivering sediment samples; Teresa Sawyer, Electron Microscopy Facility Instrument Manager, Oregon State University, for assistance with the SEM imaging; and AnneMarie Girard for assisting with the confocal microscope system. We also acknowledge the Confocal Microscopy Facility of the Center for Genome Research and Biocomputing at Oregon State University, which is supported in part by award number 1337774 from the National Science Foundation.

\section{LITERATURE CITED}

Aller RC, Yingst JY, Ullman WJ (1983) Comparative biogeochemistry of water in intertidal Onuphis (Polychaeta) and Upogebia (Crustacea) burrows: temporal patterns and causes. J Mar Res 41:571-604

Aller RC, Aller JJ, Zhu Q, Heilbrun C, Klingensmith I, Kaushik A (2019) Worm tubes as conduits for the electrogenic microbial grid in marine sediments. Sci Adv 5: eaaw3651

Bolyen E, Rideout JR, Dillon MR, Bokulich NA and others (2019) Reproducible, interactive, scalable and extensible microbiome data science using QIIME 2. Nat Biotechnol 37:852-857

Bosley KM, Copeman LA, Dumbauld BR, Bosley KL (2017) Identification of burrowing shrimp food sources along an estuarine gradient using fatty acid analysis and stable isotope ratios. Estuaries Coasts 40:1113-1130

Callahan BJ, McMurdie PJ, Rosen MJ, Han AW, Johnson AJA, Holmes SP (2016) DADA2: high-resolution sample inference from Illumina amplicon data. Nat Methods 13: 581-583

Chapman JW, Dumbauld BR, Itani G, Markham JC (2012) An introduced Asian parasite threatens northeastern Pacific estuarine ecosystems. Biol Invas 14:1221-1236

Coelho VR, Cooper RA, de Almeida Rodrigues S (2000) Burrow morphology and behavior of the mud shrimp Upogebia omissa (Decapoda: Thalassinidea: Upogebiidae). Mar Ecol Prog Ser 200:229-240

* D'Andrea AF, DeWitt TH (2009) Geochemical ecosystem engineering by the mud shrimp Upogebia pugettensis (Crustacea: Thalassinidae) in Yaquina Bay, Oregon: density-dependent effects on organic matter remineralization and nutrient cycling. Limnol Oceanogr 54:1911-1932

Dumbauld BR, Chapman JW, Torchin ME, Kuris AM (2011) Is the collapse of mud shrimp (Upogebia pugettensis) populations along the Pacific coast of North America caused by outbreaks of a previously unknown bopyrid isopod parasite (Orthione griffenis)? Estuaries Coasts 34: 336-350

Fernández-Gómez B, Richter M, Schüler M, Pinhassi J, Acinas SG, González JM, Pedrós-Alió C (2013) Ecology of marine Bacteroidetes: a comparative genomics approach. ISME J 7:1026-1037
Foster ZSL, Sharpton TJ, Grünwald NJ (2017) Metacoder: an $\mathrm{R}$ package for visualization and manipulation of community taxonomic diversity data. PLOS Comput Biol 13: e1005404

Foster ZSL, Chamberlain S, Grünwald NJ (2018) Taxa: an R package implementing data standards and methods for taxonomic data. F1000Res 7:272

FFuerst JA, Sagulenko E (2011) Beyond the bacterium: planctomycetes challenge our concepts of microbial structure and function. Nat Rev Microbiol 9:403-413

Geelhoed, JS, van de Velde, SJ, Meysman, FJR (2020) Quantification of cable bacteria in marine sediments via qPCR. Front Microbiol 11:1506

* Geerlings NMJ, Zetsche EM, Hidalgo Martinez S, Middelburg JJ, Meysman FJR (2019) Mineral formation induced by cable bacteria performing long-distance electron transport in marine sediments. Biogeosciences 16:811-829

Harris JM, Seiderer LJ, Lucas MI (1991) Gut microflora of two saltmarsh detritivore thalassinid prawns, Upogebia africana and Callianassa kraussi. Microb Ecol 21:277-296

Hiebert TC, Butler BA, Shanks AL (2015) Oregon estuarine invertebrates: Rudys' illustrated guide to common species, $3^{\text {rd }}$ edn. University of Oregon, Oregon Institute of Marine Biology, Charleston, OR

Johns AR, Taylor AC, Atkinson RJA, Grieshaber MK (1997) Sulphide metabolism in thalassinidean Crustacea. J Mar Biol Assoc UK 77:127-144

Jørgensen BB (1982) Mineralization of organic matter in the sea bed - the role of sulphate reduction. Nature 296: 643-645

Kinoshita K (2002) Burrow structure of the mud shrimp Upogebia major (Decapoda: Thalassinidea: Upogebiidae). J Crustac Biol 22:474-480

Kinoshita K, Itani G (2005) Interspecific differences in the burrow morphology between the sympatric mud shrimps, Austinogebia narutensis and Upogebia issaeffi (Crustacea: Thalassinidea: Upogebiidae). J Mar Biol Assoc UK 85:943-947

Kinoshita K, Wada M, Kogure K, Furota T (2003) Mud shrimp burrows as dynamic traps and processors of tidalflat materials. Mar Ecol Prog Ser 247:159-164

Koike I, Mukai H (1983) Oxygen and inorganic nitrogen contents and fluxes in burrows of the shrimps Callianassa japonica and Upogebia major. Mar Ecol Prog Ser 12:185-190

* Larsen S, Nielsen LP, Schramm A (2015) Cable bacteria associated with long-distance electron transport in New England salt marsh sediment. Environ Microbiol Rep 7:175-179

* Li J, Ó Foighil D, Middelfart P (2012) The evolutionary ecology of biotic association in a megadiverse bivalve superfamily: sponsorship required for permanent residency in sediment. PLOS ONE 7:e42121

Li C, Reimers CE, Alleau Y (2020) Inducing the attachment of cable bacteria on oxidizing electrodes. Biogeosciences 17:597-607

Malkin SY, Meysman FJR (2015) Rapid redox signal transmission by 'cable bacteria' beneath a photosynthetic biofilm. Appl Environ Microbiol 81:948-956

Malkin SY, Rao AMF, Seitaj D, Vasquez-Cardenas D (2014) Natural occurrence of microbial sulphur oxidation by long-range electron transport in the seafloor. ISME J 8: 1843-1854

*Malkin SY, Seitaj D, Burdorf LDW, Nieuwhof S and others (2017) Electrogenic sulfur oxidation by cable bacteria in bivalve reef sediments. Front Mar Sci 4:28 
Markham JC (2005) New species and records of Bopyridae (Crustacea: Isopoda) infesting species of the genus Upogebia (Crustacea: Decapoda: Upogebiidae): the genus Progebiophilus Codreanu \& Codreanu, 1963; and remarks on Phyllodurus Stimpson, 1857. Proc Biol Soc Wash 118: 84-95

Martin BC, Bougoure J, Ryan MH, Bennett WW and others (2019) Oxygen loss from seagrass roots coincides with colonisation of sulphide-oxidising cable bacteria and reduces sulphide stress. ISME J 13:707-719

McMurdie PJ, Holmes S (2013) Phyloseq: an R package for reproducible interactive analysis and graphics of microbiome census data. PLOS ONE 8:e61217

Müller H, Bosch J, Griebler C, Damgaard L, Nielsen L, Lueders T, Meckenstock RU (2016) Long-distance electron transfer by cable bacteria in aquifer sediments. ISME J 10:2010-2019

Müller H, Marozava S, Probst AJ, Meckenstock RU (2020) Groundwater cable bacteria conserve energy by sulfur disproportionation. ISME J 14:623-634

Oliveros JC (2015) Venny. An interactive tool for comparing lists with Venn's diagrams. https://bioinfogp.cnb.csic.es/ tools/venny/index.html

Pfeffer C, Larsen S, Song J, Dong M and others (2012) Filamentous bacteria transport electrons over centimetre distances. Nature 491:218-221

* Pohlner M, Dlugosch L, Wemheuer B, Mills H, Engelen B, Reese BK (2019) The majority of active Rhodobacteraceae in marine sediments belong to uncultured genera: a molecular approach to link their distribution to environmental conditions. Front Microbiol 10:659

Powell RR (1974) The functional morphology of the fore-guts of the thalassinid crustaceans, Callianassa californiensis and Upogebia pugettensis. University of California Publications in Zoology Vol 102. University of California Press, Berkeley, CA

Puttaswamygowda GH, Olakkaran S, Antony A, Kizhakke Purayil A (2019) Present status and future perspectives of marine actinobacterial metabolites. In: Buddolla V (ed) Recent developments in applied microbiology and biochemistry. Academic Press, Cambridge, MA, p 307-319

Editorial responsibility: Erik Kristensen,

Odense, Denmark
Rao AMF, Malkin SY, Hidalgo-Martinez S, Meysman FJR (2016) The impact of electrogenic sulfide oxidation on elemental cycling and solute fluxes in coastal sediment. Geochim Cosmochim Acta 172:265-286

* Risgaard-Petersen N, Kristiansen M, Frederiksen RB, Dittmer AL and others (2015) Cable bacteria in freshwater sediments. Appl Environ Microbiol 81:6003-6011

Seitaj D, Schauer R, Sulu-Gambari F, Hidalgo-Martinez S and others (2015) Cable bacteria generate a firewall against euxinia in seasonally hypoxic basins. Proc Natl Acad Sci USA 112:13278-13283

* Sulu-Gambari F, Seitaj D, Acta BT (2016a) Impact of cable bacteria on sedimentary iron and manganese dynamics in a seasonally-hypoxic marine basin. Geochim Cosmochim Acta 192:49-69

Sulu-Gambari F, Seitaj D, Meysman FJR, Schauer R, Polerecky L, Slomp CP (2016b) Cable bacteria control ironphosphorus dynamics in sediments of a coastal hypoxic basin. Environ Sci Technol 50:1227-1233

Thompson RK (1972) Functional morphology of the hind-gut gland of Upogebia pugettensis (Crustacea, Thalassinidea) and its role in burrow construction. $\mathrm{PhD}$ dissertation, University of California, Berkeley, CA

Thompson RK, Pritchard AW (1969) Respiratory adaptations of two burrowing crustaceans, Callianassa californiensis and Upogebia pugettensis (Decapoda, Thalassinidea). Biol Bull (Woods Hole) 136:274-287

* Tian R, Ning D, He Z, Zhang P and others (2020) Small and mighty: adaptation of superphylum Patescibacteria to groundwater environment drives their genome simplicity. Microbiome 8:51

* Trojan D, Schreiber L, Bjerg JT, Bøggild A, Yang T, Kjeldsen KU, Schramm A (2016) A taxonomic framework for cable bacteria and proposal of the candidate genera Electrothrix and Electronema. Syst Appl Microbiol 39: 297-306

Wendeberg A (2010) Fluorescence in situ hybridization for the identification of environmental microbes. Cold Spring Harb Protoc 2010:pdb.prot5366

Williams AB (1986) Mud shrimps, Upogebia, from the Eastern Pacific (Thalassinoidea, Upogebiidae). San Diego Society of Natural History, San Diego, CA

Submitted: September 16, 2019; Accepted: July 10, 2020

Proofs received from author(s): August 13, 2020 